\title{
Exploring Innovations in Microfinance Institutions in Northern Ghana
}

\author{
Stanley Kojo Dary \\ Department of Economics and Entrepreneurship Development \\ Faculty of Integrated Development Studies \\ University for Development Studies, Tamale, Ghana \\ Tel: 233-244-170-782Ｅ-mail: sdary@uds.edu.gh \\ Haruna Issahaku (Corresponding Author) \\ Department of Economics and Entrepreneurship Development \\ Faculty of Integrated Development Studies \\ University for Development Studies, Tamale, Ghana \\ Tel: 233-244-947-903Ｅ-mail: iharuna@uds.edu.gh
}

Received: April 30, 2013 Accepted: May 13, 2013

doi:10.5296/ber.v3i1.3602 URL: http://dx.doi.org/10.5296/ber.v3i1.3602

\begin{abstract}
This paper explored innovations offered by microfinance institutions (MFIs) operating in the three northern regions of Ghana. A sample of 41 MFIs comprising savings and loans companies, credit unions, and rural banks were surveyed. Data were analysed using descriptive statistics and analysis of variance (ANOVA). The study found that MFIs in the three northern regions have introduced a wide range of innovations in the past 3 years. These innovations that have been employed at varying degrees include product innovation (savings, and loans), marketing innovations, microinsurance, location innovation, and $R \& D$ innovation. On the basis of the introduction of new loan products in the past 3 years, $4.9 \%, 39 \%, 36.6 \%$, and $19.5 \%$ of MFIs were found to be potential innovators, slow innovators, moderate innovators and high innovators respectively. The study established significant relationship between company characteristics such as frequency of board meetings, educational profile of staff, ownership structure, number of branches/outlets, years of operation, company location, and
\end{abstract}


some indicators of innovation. The adoption rate of microinsurance is found to be very low (14.6\%) among MFIs. Due to the fact that innovations come with risks, MFIs are admonished to perform risk analysis before implementing innovations. This will enable them develop effective mechanisms to address potential risks associated with the introduction of innovations.

Keywords: Microfinance institutions, Microinsurance, Product innovation, Marketing innovation, Microfinance

\section{Introduction}

The microfinance sector has evolved and developed according to different patterns and growth paths in various countries and regions (Steel and Andah, 2003). Microfinance has gone through four (4) distinct phases worldwide: phase one is where the provision of subsidized credit by Governments started in the 1950s when it was assumed that the lack of money was the ultimate hindrance to the elimination of poverty; phase two involved the provision of micro credit mainly through NGOs to the poor in the 1960s and 1970s; phase three is where the formalization of microfinance institutions (MFIs) began in the 1990s; and finally phase four is where the commercialization of MFIs gained importance with the mainstreaming of microfinance and its institutions into the financial sector (MoFEP, 2008). The 1990s, which Dichter (1999) refers to as the 'microfinance decade' experienced an accelerated growth in the number of microfinance institutions created and an increased emphasis on reaching scale, and turning into an industry (Robinson, 2001). Wenner (2002) also noted three stages in the MFI development: subsidy dependent, operationally efficient, and profitability. Microfinance institutions, which are organisations that offer financial services to the very poor (MIX, 2005) have a dual mission, which Markowski (2002) classifies as social mission and commercial mission. The social mission is to provide financial services to large numbers of low-income persons to improve their welfare and the commercial mission is to provide those financial services in a financially viable manner (Markowski, 2002). Institutions found within the microfinance industry can be classified into four general categories: informal financial service providers such as moneylenders and ROSCAs; member-owned organisations such as credit unions and self-help groups; Non-governmental organisations; and formal financial institutions such as rural banks and non-bank financial institutions (Nugroho and Miles, 2009; Helms, 2006).

Microfinance has been prioritized for decades as an instrument for fighting poverty. Microfinance is seen as very crucial to attaining the Millennium Development Goals (Little et al., 2003; UNCDF, 2006; IMF, 2005). Supporting the creation of access to formal financial services for low income households holds the promise of improving the living conditions of poor families and fostering economic development (Terberger, 2003). Increasing the access of the poor to sustainable financial services is an important part of the World Bank Africa Region's strategy for supporting the Millennium Development Goals for poverty reduction. Convenient and affordable instruments for savings, credit, insurance, and payment transfers are essential both to cope with the economic fluctuations and risks that make the poor especially vulnerable, and to take advantage of opportunities to acquire productive assets and skills that can generate increased income (Steel and Andah, 2003). In developing countries and 
particularly in deprived regions, microfinance is relevant to stimulating entrepreneurship (Nugroho and Miles, 2009). Small and medium enterprises (SMEs) cannot provide the necessary collateral demanded by formal institutions and also, the banks find it difficult to recover the high cost involved in dealing with small firms. Additionally, the associated risks involved in lending to SMEs make it unattractive for the banks to deal with them (World Bank, 1994). Therefore, many microfinance institutions have emerged to address this market failure and have become the main source of funding for micro enterprises in many developing countries.

However, for MFIs to fulfil their dual mission, it will depend largely on their capacity for innovation. As traditional banks are venturing into microfinance services provision, as number of players in the microfinance industry is increasing, as there are a myriad of challenges confronting the microfinance industry, and as there is increasing complexity in demand for microfinance services among clients, the role of innovation is very crucial, particularly in developing countries. Filpo (2006) found the impediments to the success of MFIs in developing countries to relate to scalability, sustainability, outreach and the impact of the various MFI initiatives; and indicated that these impediments can be overcome through the adoption of innovative strategies to maximize outreach and sustainability. Innovation provides easy access to accurate activities such as disbursements, repayments, deposits, withdrawals, and money transfer and thus making their completion faster and better controlled with minimal opportunity for errors. Innovative activities are not only geared towards lowering transaction cost and extending the reach of microfinance institutions but also geared towards enhancing customer convenience (Hans, 2009). The microfinance industry in most African countries remains largely underdeveloped (Gupta, 2008). Therefore technological innovations, product refinements and ongoing efforts to strengthen the capacity of African MFIs are needed to reduce costs, increase outreach and boost overall profitability (Laffourcade et al., 2005).

Innovation is key to technology adoption and creation, and to explaining the vast differences in productivity across and within countries (de Mel et al., 2009). Most innovations arise in response to the potential for added value (Rajalahti et al., 2008). Innovation is the process by which firms and organizations master and implement design, and the production of goods and services that are new to them, irrespective of whether they are new to their competitors, their country or the world (Mytelka, 2000). The OECD's Oslo Manual (2005) considers innovation as "the implementation of a new or significantly improved product, or process, a new marketing method, or a new organizational method in business practices, workplace organization or external relations". Spielman (2005) defined innovation as the continuous process of upgrading using new knowledge or the new combination of existing knowledge that is new to the local area. The OECD's Oslo Manual (2005) identified four types of innovation: product innovation, process innovation, marketing innovation, and organizational innovation. Schmidt and Rammer (2006) indicated that product and process innovations are linked to marketing and organisational innovations. A firm which introduces a product innovation can be expected to improve or at least change its marketing strategy for the introduction of this product. In a study, de Mel et al. (2009) found product and marketing innovation to be common in small firms while process and organizational innovations were much less common. In 
developing countries, incremental changes, acquisition of embodied technology, and applications or adaptations of existing products or processes are thought to be the most frequent forms of innovation (de Mel et al., 2009).

Worldwide, the empirical literature on microfinance innovations may have been commonplace, but it is seriously lacking in Ghana. Most studies on microfinance in Ghana have focused on the impact of microfinance on poverty reduction (eg. Addae-Korankye, 2012; Adams, 2010; Awaworyi and Danso, 2010). While this approach is not out of place, the ability of microfinance institutions to remain sustainable and to eradicate poverty will to a very large extent depend on their degree of innovativeness. The only study on innovations in MFIs on Ghana so far identified is one by Opare-Djan (2008). Opari-Djan (2008) examined innovative and unique dimensions of Kraban Support Foundation's micro-loan products using a sample of seven (7) MFIs. The study identified innovative microfinance products such as funeral loans, church loans, fishermen loans, salaried loans among others. It is clear from the above that the study limited its self to loan product innovation, ignoring saving product innovation, marketing innovations and input innovation (eg. R\&D). The current study cures these inadequacies by examining innovation by MFIs in terms of product innovation (loan and savings products), market innovation, and input innovation $(\mathrm{R} \& \mathrm{D}$, educational profile and experience of workers, etc.). From the foregoing discussion, what is clear is that more studies on innovations by MFIs are required.

It is in contributing to curing this paucity of empirical evidence on innovation by MFIs in Ghana that this study has been carried out. This study characterizes microfinance institutions operating in the northern regions of Ghana and examines the influence of these characteristics on product, marketing and input innovations within microfinance institutions. Nugroho and Miles (2009, pp. 21) have argued that at "the heart of this innovation is the development of methods to deliver loans to vulnerable individuals or groups, with little or no collateral". According to the Ghana Statistical Service (2007), the three northern regions are the most deprived and poverty stricken regions of Ghana, with Upper West Region, Upper East Region and Northern Region recording poverty incidence of $88 \%, 70 \%$ and $52 \%$ respectively. On the basis of this, 41 microfinance institutions operating in the three northern regions formed the sample for this study. Sustainable microfinance delivery is very crucial to fighting poverty by enabling the poor to start-up and grow existing small and microenterprises. The results from the study will therefore be relevant in designing programmes/projects and adopting strategies to encourage innovation, competitiveness and sustainability of microfinance institutions.

\section{Methodology}

\subsection{Data Collection}

The study focussed on microfinance institutions in the three northern regions of Ghana. Data were collected in 2012. The microfinance institutions considered were rural and community banks, cooperative credit unions, and loans and savings companies. From the seventy (70) questionnaires that were distributed to microfinance institutions across the regions, 50 questionnaires were retrieved, constituting 71\%. However, nine institutions responded partially to the questionnaires, hence restricting the use of their data for analysis. Therefore this 
study is based on the analysis of data of 41 microfinance institutions from 13 administrative districts in the study area. Table 1 presents the types and distribution of sampled microfinance institutions for the study.

Table 1. Types and Distribution of Microfinance Institutions Sampled

\begin{tabular}{|l|l|l|l|l|}
\hline Institution Type & $\begin{array}{l}\text { Northern } \\
\text { Region }\end{array}$ & $\begin{array}{l}\text { Upper East } \\
\text { Region }\end{array}$ & $\begin{array}{l}\text { Upper West } \\
\text { Region }\end{array}$ & Total \\
\hline Rural Banks & 3 & 2 & 3 & 8 \\
\hline Cooperative Credit Unions & 6 & 5 & 5 & 16 \\
\hline Savings and Loans Companies & 5 & 7 & 5 & 17 \\
\hline Total & 14 & 14 & 13 & 41 \\
\hline
\end{tabular}

\subsection{Indicators of Innovations}

There is no consensus as to the set of indicators of innovation in MFIs. On the basis of this, various authors have constructed their own indicators of innovation. Innovation can be measured using either the input approach or the output approach. The input approach looks at activities in the firm that stimulate or induce innovation. Such activities include R \& D investments, level of education of workers, level of experience of workers among others. The output approach looks at the outcomes of innovation inputs as they relate to product, process, marketing, and organizational arrangements. Based on the output approach, the OECD's Oslo Manual (2005) has identified four main types of innovation: product innovation, process innovation, marketing innovation, and organizational innovation.

Flynn (1994) has classified firms into slow innovators, medium innovators and fast innovators. In the same vein, Freeman (1986) has differentiated between incremental, radical, and revolutionary innovations. Booz et al. (1982) classified innovation into (1) new to the industry innovations (2) new product lines (3) additions to existing product lines (4) improvements and revisions to existing products (5) repositionings, and (6) cost reductions. Similarly, Lovelock (1984) classified innovations into major innovations, new products for the currently served market, product lines extension, product improvements, and style changes. Some authors (eg. Vilaseca-Requena et al., 2007) have just simply classified firms into innovative and non-innovative firms. Other authors (eg. Nugroho and Miles, 2009) have argued that microfinance itself is an innovation; stimulates innovation; and can be innovated.

Based on the lack of a unified way of measuring innovations in MFIs, this study, drawing on the above literature has developed a wide range of indicators to measure microfinance innovations. This is shown in Table 2.

Table 2. Measurement of Innovation

\begin{tabular}{|l|ll|}
\hline $\begin{array}{l}\text { Dimension/Level of } \\
\text { Innovation }\end{array}$ & Indicators \\
\hline Input Approach & & \\
\hline R \& D Investments & $\checkmark$ & Whether MFI invests in R\&D \\
& $\checkmark$ & Total R\&D expenditure \\
\hline Educational profile of staff & $\checkmark$ & Number of years of schooling by staff \\
\hline
\end{tabular}




\begin{tabular}{|l|l|}
\hline Work experience of staff & $\checkmark$ Number of years worked by staff \\
\hline Output Approach & \\
\hline Loan product innovation & $\checkmark$ Number of loan products offered by firm \\
& $\checkmark$ Number of new loan products introduced in the past 3 \\
& years \\
& $\checkmark \quad$ Modifications made to existing loan products in the past 3 \\
& years \\
\hline Savings product innovation & $\checkmark \quad$ Number of savings products offered by firm \\
& $\checkmark \quad$ Number of new savings products introduced in the past 3 \\
& years \\
& $\checkmark \quad$ Modifications made to existing savings products in the \\
& past 3 years \\
\hline Marketing innovation & $\checkmark \quad$ Whether marketing innovations have been introduced in \\
& the past 3 years \\
& $\checkmark \quad$ Modifications made to existing marketing products in the \\
& past 3 years \\
\hline Microinsurance & $\checkmark \quad$ Whether microinsurance is offered by firm \\
\hline Location Approach & $\checkmark$ Number of branches/outlets operated by firm \\
\hline Location innovation & $\checkmark$
\end{tabular}

Source: Authors' construction

Pearce and Robison (2011) described adjustments or simple changes to existing products, services, or processes as incremental innovations. According to the authors, companies that seek to boost payoff from innovation investments achieve better results by concentrating on incremental innovations. Incremental innovations covered in this study include modifications to existing savings and loan products as well as modification to existing marketing strategies. Major drivers of incremental innovation include continuous improvement, cost reduction and quality management (Pearce and Robinson, 2011).

\subsection{Data Analysis and Tests of Significance}

Descriptive statistics such as mean, maximum, minimum, percentages, frequencies, and standard deviations are used to describe the characteristics of MFIs and the various innovations they have. In order to test the relationship between firm characteristics and the innovation dimensions above, the study employed analysis of variance (ANOVA). The essence is to identify which specific characteristics of firms influence innovation.

\section{Results and Discussion}

\subsection{Company Characteristics}

Some company characteristics of MFIs are found in Table 3. The company characteristics covered include board characteristics, years of operation, sex representation in board, size of workforce, sex representation in workforce, and age profile of workers.

The board size ranges from 2 to 28 people with a mean board size of 7 people. The mean board 
size appears reasonable for effective decision making. The minimum board size of 2 people appears unusual and too small to allow for effective deliberations. Even though there is no such thing as the "right number" of board size, some experts (eg. Temkin, 2011) have recommended a size of 9 to 15 . It is the view of the researchers that, given that there is no magic formula in computing board size, each corporation must learn from the experiences of similar firms as well as its own experience to arrive at a "suitable" board size. In terms of sex representation, some boards have no female representation while others have as many as 8 females, with an average of approximately 2 females. As will be expected, males dominate boards with a range of 1 to 16 and an average of 5. Thus, the average representation of males more than doubles the average female representation. To enrich board decisions and to stimulate innovations, MFIs are encouraged to include more females in their boards. Other board characteristics such as meeting frequency per year and board tenure are shown in Table 3.

The size and quality of workforce is both an indicator and a determinant of innovation. The size of the workforce is one of the measures of size of an organisation. Schmidt and Rammer (2006) indicate that the number and composition of employees impacts on a firm's innovative behaviour. The size of workforce of MFIs in northern Ghana ranges from 2 to 63 people with an average of 10 , indicating that the MFIs are relatively small in size. In terms of gender composition of workforce, the mean composition for males and females is 4 and 3 respectively. The age of the workforce is within the range of 23 to 36 years with an average of 29 years. This is a very youthful workforce. While one may argue that this youthful workforce of MFIs will encourage innovations due to the fact that the youth are well known for their adventurism (which may lead to discoveries), on the other hand it can be argued that the seaming inexperience (assuming that there is a linear relationship between age and experience) may derail the success of innovations even if they are found and implemented.

The years of operation ranges from 1 to 40 years with an average of 7 years. It is expected that the longer the number of years a company is in operation, the more experience it accumulates, and if experience accounts for innovation, then the more innovative the firm can be. It may be argued on the other hand that longevity has its own disadvantages, one being the tendency to want to stick to the status quo (business as usual). Some of the MFIs are well-branched. While some have as many as 48 branches/outlets others have as few as a branch. The average branch/outlet size is 5. For those with few branches/outlets, innovation can accelerate their branching derive. For those with many branches/outlets, innovation will enable them maintain their client base and if possible attract and retain new ones.

\subsection{Operational Characteristics of MFIs in Northern Ghana}

Some operational characteristics of MFIs are displayed in Table 3. These include interest rate, minimum loan amount over the past 3 years, maximum loan amount over the past 3 years, repayment rate over the past 3 years, and clientele base over the past 3 years. The mean interest rate charged by MFIs over the past 3 years is $25 \%$ per annum. Although this compares favourably with the average interbank interest rate, it could have been lower. Given that one of the major objectives of MFIs is to alleviate poverty and that activities engaged in by most of their clientele are small scale and low return activities, the rates charged by MFIs should be 


\section{MInstitute Macrothink $_{\text {Int }}$}

Business and Economic Research ISSN 2162-4860 2013, Vol. 3, No. 1

lower than commercial bank rates. The lending rates of commercial banks declined from $27.3 \%$ in 2010 to $25.93 \%$ in 2011 (ISSER, 2012). Some MFIs charge as high as $78 \%$ interest rate per annum which is definitely a poverty enhancing rate. Given a lowering of inflation to single status over the past 3 years, an interest rate of $18 \%-20 \%$ will not be unprofitable to MFIs.

The average minimum loan given to clients over the past 3 years is GHC144 while the average maximum loan is GHC7,198.78. While the minimum loan amount largely depends on the needs of the client, the maximum loan usually is a company policy. Given the need to exploit more business opportunities in the North, where the capacity and risk assessment of an MFI will permit, the maximum loan amount should be raised (this may constitute a new-to-the-firm-innovation). This will enable clients to take advantage of capital intensive but highly profitable investment opportunities. The sustainability of any microcredit scheme depends on the repayment rate. In the past 3 years the maximum repayment rate has been $100 \%$ while the minimum repayment rate has been $56 \%$. The minimum recovery rate of $56 \%$ is quite low and may affect the sustainability of such MFIs as their loan portfolios are highly represented by delinquent loans. This requires an assessment of such default scenarios to enable the deployment of effective strategies to bring default rates to the barest minimum. The clientele base is quite impressive. The maximum clientele base is 5,375 while the minimum is 871. Given the pervasive nature of poverty in the north, there is a great opportunity for MFIs to expand their client base which can be made possible by the introduction of effective innovations. The researchers also agree with the suggestion by ISSER (2012) that MFIs should expand their existing strategies and diversify their funds to the underserved Micro, Small and Medium Enterprises (MSME) sector.

Table 3. Descriptive Statistics of Company and Business Operational Characteristics

\begin{tabular}{|c|c|c|c|c|c|}
\hline & $\mathrm{N}$ & Minimum & Maximum & Mean & Std. Deviation \\
\hline Number of Branches/Outlets & 41 & 1.00 & 48 & 5.22 & 9.23 \\
\hline Years in Operation & 40 & 1.00 & 40.0 & 7.44 & 7.94 \\
\hline Size of Board & 38 & 2.00 & 24 & 7.21 & 3.43 \\
\hline Females on Board & 38 & 0.00 & 8.00 & 1.84 & 1.41 \\
\hline Males on Board & 38 & 1.00 & 16.00 & 5.37 & 2.58 \\
\hline Board Tenure & 32 & 1.00 & 5.00 & 2.56 & 1.01 \\
\hline $\begin{array}{c}\text { Frequency of Board } \\
\text { Meetings }\end{array}$ & 34 & 1.00 & 12.00 & 5.44 & 4.42 \\
\hline Size of Workforce & 41 & 2.00 & 63 & 9.63 & 9.70 \\
\hline Number of Males & 40 & 1.00 & 10 & 4.43 & 2.29 \\
\hline Number of Females & 40 & 0.00 & 11 & 3.25 & 2.25 \\
\hline $\begin{array}{c}\text { Average Level of Education } \\
\text { of Workforce }\end{array}$ & 40 & 1.60 & 3.00 & 2.52 & 0.34 \\
\hline Age of Employees & 39 & 23.13 & 36.33 & 28.98 & 3.75 \\
\hline $\begin{array}{c}\text { Average Years of Work with } \\
\text { MFI }\end{array}$ & 35 & 0.48 & 7.80 & 2.67 & 1.51 \\
\hline
\end{tabular}




\begin{tabular}{|c|c|c|c|c|c|}
\hline $\begin{array}{c}\text { Investment in Research and } \\
\text { Development (R\&D) }\end{array}$ & 41 & 0.00 & 1 & .54 & 0.51 \\
\hline R\&D Expenditure & 38 & 0.00 & 62760.00 & 3353.55 & 11395.36 \\
\hline $\begin{array}{c}\text { Average Interest Rate for the } \\
\text { past 3 Years }\end{array}$ & 41 & 0.00 & 78.00 & 25.1967 & 13.14 \\
\hline Average Repayment Rate & 41 & 0.00 & 100.00 & 55.76 & 36.74 \\
\hline $\begin{array}{c}\text { Average Loan Portfolio over } \\
\text { the past 3 Years }\end{array}$ & 41 & 0.00 & 895666.67 & 107826.35 & 178263.62 \\
\hline $\begin{array}{c}\text { Average Clientele Base for } \\
\text { the past 3 Years }\end{array}$ & 41 & 0.00 & 5375.00 & 871.19 & 1199.22 \\
\hline $\begin{array}{c}\text { Minimum amount of Loan } \\
\text { given to Clients }\end{array}$ & 41 & 0.00 & 500.00 & 144.39 & 114.26 \\
\hline $\begin{array}{c}\text { Maximum Loan amount } \\
\text { given to Clients }\end{array}$ & 41 & 0.00 & 68333.33 & 7198.78 & 11725.20 \\
\hline $\begin{array}{c}\text { Average Maximum Loan } \\
\text { Term }\end{array}$ & 41 & 0.00 & 72.00 & 33.67 & 18.76 \\
\hline $\begin{array}{c}\text { Average Minimum Loan } \\
\text { Term }\end{array}$ & 41 & 0.00 & 12.00 & 5.38 & 3.71 \\
\hline $\begin{array}{c}\text { Number of Loan Products } \\
\text { offered in the past 3 Years }\end{array}$ & 41 & 0.00 & 5.00 & 2.27 & 1.38 \\
\hline $\begin{array}{c}\text { Number of Savings Products } \\
\text { offered }\end{array}$ & 35 & 1.00 & 5.00 & 2.51 & 1.20 \\
\hline $\begin{array}{c}\text { Number of Loan Products } \\
\text { offered }\end{array}$ & 41 & 1.00 & 6.00 & 3.44 & 1.23 \\
\hline $\begin{array}{c}\text { Number of Savings Products } \\
\text { offered in the past 3 Years }\end{array}$ & 33 & 0.00 & 4.00 & 1.42 & 1.15 \\
\hline
\end{tabular}

\subsection{Indicators of Innovation in MFIs}

\subsubsection{Input Based Measures of Innovation in MFIs}

In this paper, the main input measure of innovation is investment in R\&D. Other input measures explored include the educational and work experience of staff. The statistics are shown in Tables 3 and 4. About $66.3 \%$ of MFIs invest in R\&D while the remaining $43.3 \%$ do not. The view has often been held that $R \& D$ is a major driver of innovation. The average $R \& D$ expenditure is GHC3,353.55 with a maximum of GHC62,760.00 per annum. Based on these R\&D statistics, it can be concluded that over $60 \%$ of MFIs can be classified as innovators. R\&D outfits must be set up by MFIs. These outfits should be tasked with the formulation of documented innovation plans (de Jong and Vermeulen, 2004), product research, and marketing research among others. For firms to compete well in their industry, they need to understand the threats presented by the industry environment and competitors. For this to be realised, setting up and financing R\&D departments will be essential.

The level of experience of employees in MFIs is an average of 2.6 years which is quite low and may also represent high employee turnover. High employee turnover erases the institutional 


\section{Macrothink}

Business and Economic Research ISSN 2162-4860 2013, Vol. 3, No. 1

memory needed to support innovation. Experience is important and MFIs should motivate their employees to stay so that they can benefit from their experience and investment in their training.

Table 4. Descriptive Statistics on Innovations by MFIs

\begin{tabular}{|c|c|c|}
\hline Variable & Frequency & Percent \\
\hline \multicolumn{3}{|c|}{ Type of Microfinance Institution } \\
\hline Rural Bank & 8 & 19.5 \\
\hline $\begin{array}{l}\text { Savings and Loans } \\
\text { Companies }\end{array}$ & 17 & 41.5 \\
\hline Coop. Credit Union & 16 & 39.0 \\
\hline \multicolumn{3}{|l|}{ Investment in R\&D } \\
\hline Yes & 22 & 66.3 \\
\hline No & 19 & 43.3 \\
\hline \multicolumn{3}{|l|}{ Loan Products Offered } \\
\hline Yes & 41 & 100 \\
\hline No & 0 & 0 \\
\hline \multicolumn{3}{|c|}{ Degree of Product Innovation } \\
\hline Potential Innovators & 2 & 4.9 \\
\hline Slow Innovators & 16 & 39.0 \\
\hline Moderate Innovators & $\begin{array}{l}15 \\
8\end{array}$ & $\begin{array}{l}36.6 \\
195\end{array}$ \\
\hline \multicolumn{3}{|c|}{ Modification to existing Loan Products } \\
\hline Yes & 15 & 36.6 \\
\hline No & 26 & 63.4 \\
\hline \multicolumn{3}{|l|}{ Offer Savings Products } \\
\hline Yes & 35 & 85.4 \\
\hline No & 6 & 14.6 \\
\hline \multicolumn{3}{|c|}{ Modifications to existing Savings Products } \\
\hline Yes & 10 & 30.3 \\
\hline No & 23 & 69.7 \\
\hline \multicolumn{3}{|c|}{ Marketing Innovation in past 3 Years } \\
\hline Yes & 33 & 80.5 \\
\hline No & 8 & 19.5 \\
\hline \multicolumn{3}{|c|}{ Modification to existing Marketing Innovations } \\
\hline Yes & 16 & 39.0 \\
\hline No & 25 & 61.0 \\
\hline \multicolumn{3}{|c|}{ Offer Micro insurance? } \\
\hline Yes & 6 & 14.6 \\
\hline No & 35 & 85.4 \\
\hline
\end{tabular}




\subsection{Output Measures of Innovation}

\subsubsection{Product Innovation}

\section{Loan Product Innovations}

The number of new loan products introduced within the past 3 years, modifications made to existing loan products in the past 3 years, the number of new savings products introduced within the past 3 years, and modifications made to existing savings products in the past 3 years have been used as measures of product innovation. Based on the number of new loan products (since all MFIs in the sample give loans) introduced in the past 3 years, MFIs have been classified as potential innovators, slow innovators, moderate innovators, and high innovators. Potential innovators are MFIs who have introduced no new loan product over the past 3 years. For these firms, there is an unlimited room for innovations. In our sample, only $4.9 \%$ of MFIs are potential innovators. Slow innovators are MFIs that have introduced only 1 new loan product in the past 3 years. This constitutes about $39 \%$ of our sample -a majority of the sample. Moderate innovators have introduced between 2-3 new loan products and about $36.6 \%$ of MFIs falls under this category. We defined MFIs that have introduced at least 4 new loans in the past 3 years as being highly innovative. About $19.5 \%$ of MFIs falls within this category. Generally, MFIs are largely loan product-innovative based on the findings. This is important because the financial sector is highly competitive and for MFIs to compete well against the well-established commercial banks who also offer loan packages, they need to introduce customised products to suit the peculiar needs of their clients. Some of the innovative loans introduced by MFIs include funeral loans, church loans, fishermen loans, salaried loans, PCIP, BEAM, SANKOFA, ORACLE, READY, TEACH 1, TEACH II, TEACH III, SIKA ROSE, AGAPE \& EXTRA MILE (Opare-Djan, 2008). Out of their experiences firms may decide to modify existing products to suit the needs of the market and to reduce risk. About $36.6 \%$ of MFIs modified existing loan products while the remaining $63.7 \%$ did not.

\section{Savings Product Innovation}

The number of new savings products introduced in the last three years ranges from 0 to 4 (see Table 3) with an average of about 2 products. For the $85.4 \%$ of MFIs who offer savings products, only $30.3 \%$ made modifications to existing savings products in the past 3 years while the majority $(69.7 \%)$ made no modification to savings products within the same period (see Table 4). It appears from this result that MFIs are more innovative in loan products than in savings products. The reason may be the higher margins that firms gain from giving out loans to clients. But neglecting savings product may lead the MFIs into serious difficulties since savings are a means of repayment of loans by clients and also a source of funding for MFIs. The various savings products offered by MFIs are shown in Table 5.

Table 5. Savings Products offered by MFIs

\begin{tabular}{|l|l|l|}
\hline Savings Products & Frequency & \% of MFIs \\
\hline Current account & 8 & 19.5 \\
\hline Daily savings/Susu & 16 & 39 \\
\hline Savings account (Individual) & 34 & 82.9 \\
\hline
\end{tabular}




\begin{tabular}{|l|l|l|}
\hline Savings account (Group) & 10 & 24.4 \\
\hline Fixed term deposit & 16 & 39 \\
\hline Child education savings package/top scholar & 5 & 12.2 \\
\hline Hajj savings & 1 & 2.4 \\
\hline Youth savings & 3 & 7.3 \\
\hline Sallah/Christmas savings & 1 & 2.4 \\
\hline Special savings & 1 & 2.4 \\
\hline
\end{tabular}

\subsubsection{Marketing Innovations}

Firms innovate in marketing by developing new ways of advertising, branding, discovering new markets and market segments. They could also innovate by modifying existing marketing strategies to suit their target market and to mitigate risk. The results show that marketing innovation is high among the MFIs. Majority of MFIs (80.5\%) introduced marketing innovations in the past 3 years. Most MFIs get to the street, move into homes and other places to advertise and market their products. Others are taking advantage of the internet, radio and $\mathrm{TV}$, bill boards, the print media and a host of other platforms to make their products known to the general public. This helps MFIs to maintain old clients while attracting new ones. Given the competitive nature of the financial sector, more innovative and cost effective marketing strategies must be deployed by MFIs if they want to remain competitive and relevant. In terms of modifications to existing marketing products in the past 3 years, most MFIs (61\%) stuck to the status quo. Only $39 \%$ of MFIs modified existing marketing products. This may suggest that existing marketing products are relatively working well as new strategies are developed and added to the marketing products pool. Presented in Table 6 are various marketing innovations MFIs employ to attract and retain clients. They are diverse and factors such as type of MFI, size of the MFI, geography, clients' characteristics and the presence of infrastructure can influence the choice(s) of marketing innovation(s) among the MFIs. Radio advertisement, mobile banking/personal selling (door-to-door), posters, and bill boards dominate the marketing innovations MFIs employ to reach out and sell their products to clients in northern Ghana.

Table 6. Marketing Innovations by MFIs

\begin{tabular}{|l|l|l|}
\hline Marketing Products & Frequency & \% of MFIs \\
\hline Higher loan amount for on-time payment & 3 & 7.3 \\
\hline Radio advertisement and selling & 28 & 68.3 \\
\hline Posters & 18 & 44 \\
\hline Use of billboards & 11 & 27 \\
\hline Mobile banking/personal selling & 20 & 51 \\
\hline Special promotions & 4 & 10 \\
\hline Television advertisement/Telemarketing & 6 & 10 \\
\hline Letters/ emails/website creation & 1 & 2.4 \\
\hline Sponsorship of programs & 1 & 2.4 \\
\hline $\begin{array}{l}\text { Visit to institutions/organisations eg. } \\
\text { Churches, Mosques etc. }\end{array}$ & 8 & 20 \\
\hline Use of flyers & 6 & 15 \\
\hline
\end{tabular}




\begin{tabular}{|l|l|l|}
\hline $\begin{array}{l}\text { Lowering bank charges/interest for } \\
\text { on-time payment }\end{array}$ & 3 & 7.3 \\
\hline Customer appreciation/awards/care & 2 & 5 \\
\hline Using General Meetings & 4 & 10 \\
\hline Flexible minimum balance & 2 & 5 \\
\hline
\end{tabular}

\subsubsection{Microinsurance}

Microinsurance is a mechanism to protect poor people against risk (accidents, illness, death in the family, floods, droughts and other natural disasters, etc.) in exchange for insurance premium payment tailored to their needs, income and level of risk. Essentially, microinsurance designs insurance products that offer coverage to low-income persons and households. A microinsurance plan offers protection to individuals who have little savings and is custom-made for lower valued assets and compensation for illness, injury or death (Investopedia, 2013). Since microinsurance is quite new to the Ghanaian financial sector, the study regarded it as an innovation. Being a relatively new area, only $14.6 \%$ of MFIs offer microinsurance. Because of issues of adverse selection and moral hazards, even mainstream insurance companies shy away from microinsurance. This is an area MFIs can really innovate to carve a niche for themselves. R\&D outfits must be well resourced to develop microinsurance products that mitigate risks for both the insured and the insurer.

\subsection{Location Approach to Innovation}

One aspect of innovation that has been ignored in the literature is location. Institutions can innovate by simply increasing their operational coverage to a wider geographical area. This enables such institutions to get new clients by taking advantage of the underserved nature of new environments. One way of innovating geographically is to open new branches/outlets. According to Cracknell (2005) branches/outlets should be located in areas that allow the institution to provide accessible, frequent and convenient services to its customers. Though branching is an indicator of innovation, other innovations such as product, process and marketing innovations are required for the successful creation and sustainability of branches/outlets. Some of the MFIs are well-branched. While some have as many as 48 branches others have as few as a branch. The average branch size is 5 (see Table 3). For those with few branches/outlets, innovation can accelerate their branching derive. For those with many branches/outlets, innovation will enable them maintain their client base and if possible attract and retain new ones.

\subsection{Effect of Company Characteristics on Innovation}

To determine the effect of company characteristics on innovation by MFIs, the company characteristics were each run against each innovation indicator based on the ANOVA framework. Significant relations that emerged were extracted and displayed in Table 7. In this study, number of branches/outlets is both a determinant and an indicator of innovation. As a determinant of innovation, the number of branches/outlets affects investment in R\&D and the introduction of new savings products. The plausible explanation is that opening a new branch/outlet will require more research to understand the context the MFI is operating. Also, a 
new location will require the development of new savings products to meet the peculiar needs of the new clientele. These initiatives make the MFI competitive in the new location. As an indicator of innovation the number of branches/outlets of an MFI depends on the number of staff with tertiary education. This is rational because the opening up and sustenance of a branch/outlet will require appointment of a branch/outlet manager and the conduct of feasibility surveys. This will require staff that has higher educational attainment (tertiary). This confirms the finding of Lin (1990), who through a dichotomous probit model and a two-limit tobit model, established a positive effect of education on the adoption of new technology.

Location appears to be an important factor in determining innovations in MFIs. It affects the modification of existing loan products, introduction of marketing innovation, and the number of savings products introduced. About $78.6 \%$ of MFIs in the UER are either moderate innovators or high innovators compared to $50 \%$ and $35.7 \%$ of MFIs in UWR and NR respectively. The high number of innovative firms in UER and to some extent UWR may be due to the fact that new branches/outlets are being opened; and new products are being developed to meet the needs of the largely underserved populace. Findings by Hamel (2000), Porter and Stern (2001), and Porter (1998) all confirm the effect of location on innovation. According to the authors, the socio-economic environment of a location, such as human capital, or the existence of certain institutions, has a strong impact on the companies located in this area with regards to their innovativeness.

The type of MFI also affects the level of innovation. Innovations such as number of branches/outlets, marketing innovations and microinsurance vary significantly based on the type of MFI.

Table 7. ANOVA on Impact of Firm Characteristics on Innovation

\begin{tabular}{|c|c|c|c|}
\hline Factor & Dependent Variable & F-Statistic & Sig. \\
\hline \multirow{2}{*}{$\begin{array}{l}\text { No. of } \\
\text { Branches/outlets }\end{array}$} & Investment in $\mathrm{R} \& \mathrm{D}$ & 25.144 & .000 \\
\hline & $\begin{array}{l}\text { New savings products introduced in the past } 3 \\
\text { years }\end{array}$ & 3.074 & .018 \\
\hline \multirow[t]{4}{*}{ Location } & $\begin{array}{l}\text { Whether there has been modification to existing } \\
\text { loan products in the past } 3 \text { years }\end{array}$ & 4.230 & .022 \\
\hline & $\begin{array}{l}\text { Whether MFI has introduced any marketing } \\
\text { innovation in the past } 3 \text { years }\end{array}$ & 2.744 & .077 \\
\hline & Degree of Product Innovation & 1.937 & .016 \\
\hline & $\begin{array}{l}\text { Number of savings products offered in the past } 3 \\
\text { years }\end{array}$ & 3.435 & .045 \\
\hline \multirow[t]{3}{*}{ Type of MFI } & Number of branches/outlets & 3.602 & .037 \\
\hline & $\begin{array}{l}\text { Whether MFI has introduced any marketing } \\
\text { innovation in the past } 3 \text { years }\end{array}$ & 3.730 & .033 \\
\hline & Offer Microinsurance? & 6.067 & .005 \\
\hline \multirow{2}{*}{$\begin{array}{l}\text { Years of } \\
\text { operation }\end{array}$} & Investment in $\mathrm{R} \& \mathrm{D}$ & 2.287 & .034 \\
\hline & $\begin{array}{l}\text { Number of loan products offered in the past } 3 \\
\text { years }\end{array}$ & 2.842 & .011 \\
\hline
\end{tabular}




\begin{tabular}{|l|l|l|l|}
\hline & Degree of Product Innovation & 3.985 & .001 \\
\cline { 2 - 4 } & Offer Microinsurance? & 2.139 & .047 \\
\hline $\begin{array}{l}\text { Frequency of } \\
\text { board meetings }\end{array}$ & Offer Microinsurance? & 2.701 & .050 \\
\hline $\begin{array}{l}\text { Company } \\
\text { structure }\end{array}$ & $\begin{array}{l}\text { Number of loan products offered in the past 3 } \\
\text { years }\end{array}$ & 4.048 & .014 \\
\hline $\begin{array}{l}\text { Number of staff } \\
\text { with } \\
\text { education }\end{array}$ & R \& D expenditure & 16.890 & .000 \\
\hline $\begin{array}{l}\text { Number of staff } \\
\text { with tertiary }\end{array}$ & $\begin{array}{l}\text { Number of branches/outlets } \\
\text { an existing marketing innovation in the past 3 } \\
\text { years }\end{array}$ & 4.485 & .001 \\
\hline
\end{tabular}

All (100\%) savings and loans companies in the sample introduced new marketing innovations in the past three years compared to $75 \%$ and $64.7 \%$ respectively for rural banks and credit unions. Savings and loans companies are becoming more and more popular in the north due to their heavy advertisement and promotion drives. In terms of microinsurance, only credit unions have microinsurance packages. Even so, only $54.5 \%$ of credit unions in the sample offer microinsurance. Given that even main stream insurance companies shy away from microinsurance, the woes of the poor may be far from over. MFIs should invest more in R\&D to develop microinsurance products suited for the conditions of the poor. Government must facilitate the process by putting in place relevant legislative framework and other incentives.

Experience they say is the best teacher. The number of years of operation of an MFI which is a proxy for institutional experience has a significant impact on innovation parameters such as investment in $\mathrm{R} \& \mathrm{D}$, offer of microinsurance and the number of new loan products introduced. Over time, an MFI gathers more experience as it goes through the learning curve. This experience enables the MFI to discover new things and new ways of carrying out old tasks. Among the board characteristics, it is only frequency of board meetings that impacts on innovation (microinsurance in particular). Frequency of board meetings ranged from 1 to 12 times a year. Those MFIs that met 12 times a year were found to introduce microinsurance than all the other meeting frequencies. This implies that these meetings discuss relevant issues that have the tendency to push the organisation forward. If frequent board meetings yields more returns, it should be encouraged. Managers of MFIs must take advantage of the rich experience of their boards to formulate and implement institutional policies that encourage the development of innovative products, services, and processes.

Company structure is found to affect the number of new loan products introduced over the past 3 years. Private limited liability companies introduced more new loan products followed by public limited liability companies, and partnerships respectively. Partnerships that lack sufficient coordination may turn to hinder effective decision making and slow down innovativeness.

\section{Conclusion}




\section{Mll Macrothink}

Business and Economic Research ISSN 2162-4860 2013, Vol. 3, No. 1

This paper examined innovations offered by MFIs operating in the three northern regions of Ghana. The study found ample evidence to support the fact that MFIs in the three northern regions have introduced a wide range of innovations in the past three years. These innovations that have been employed at varying degrees include product innovation (savings, and loan), marketing innovations, microinsurance, location innovation, and R\&D innovation. Based on the introduction of new loan products in the past 3 years, $4.9 \%, 39 \%, 36.6 \%$ and $19.5 \%$ of MFIs were found to be potential innovators, slow innovators, moderate innovators and high innovators respectively. The study discovered that significant relationship exist between company characteristics such as frequency of board meetings, educational profile of staff, ownership structure, number of branches/outlets, years of operation, company location, and some indicators of innovation. The adoption rate of microinsurance is very low among MFIs. This is an area where MFIs can exploit to increase their payoffs from investments in innovations. The underserved market is huge and for it to be exploited, it will require committed efforts from the management of MFIs to develop unique microinsurance products to meet the needs of the poor and marginalised. Innovations come with risks. MFIs are advised to perform risk assessment before rolling out innovations. This will help them develop effective mechanisms to contain potential risks.

\section{Acknowledgement}

The following persons: Gbeila A. Wahab, Salifu M. Mohammed, Abdallah Maria, Hamidu Mohammed and Hamza Naftal are acknowledged for helping in collecting the data used in this report.

\section{References}

Adams, S. (2010). The Impact of Microfinance on Maize Farmers in Nkoranza (Brong Ahafo Region of Ghana). Journal of Management Research, 2(2), 1-13.

Addae-Korankye, A. (2012). Microfinance and Poverty Reduction in Ghana. The Case of Central Region of Ghana. Asian Economic and Financial Review, 2(1), 135-141.

Awaworyi, S. K., \& Korankye Danso, J. K. (2010). Poverty Reduction in Ghana-The Role of Microfinance and Socioeconomic Education. Retrieved online on $15^{\text {th }}$ April 2013 at sefakwame.files.wordpress.com/2011/03/poverty-reduction.pdf.

Bank of Ghana. (2007). A Note on Microfinance in Ghana. Working Paper WP/BOG-07/01

Hans, V. B. (2009). Innovations in Microfinance: Looking beyond income poverty. Retrieved online on $17^{\text {th }}$ April 2013 from http://ssrn.com/abstract=1392623 or http://dx.doi.org/10.2139/ssrn.1392623

Booz, A., \& Hamilton. (1982). New Products Management for the 1980s. New York, NY.

de Jong, J. P. J., \& Vermeulen, P. A. M. (2004). Determinants of Product Innovation in Small Firms: A Comparison across Industries. Paper submitted to the International Small Business Journal August 10, 2004.

De Mel, S., McKenzie, D., \& Woodruff, C. (2009). Innovative Firms or Innovative Owners? 


\section{Al Macrothink}

Business and Economic Research ISSN 2162-4860 2013, Vol. 3, No. 1

Determinants of Innovation in Micro, Small, and Medium Enterprises. IZA Discussion Paper No. 3962.

Dichter, T. M. (1999). Non-Governmental Organizations in Microfinance: Past, Present and Future -An Essay, Case Studies in Microfinance, World Bank, Washington DC, pp. 12.

Filpo, J. (2006). Banking the Unbanked: Technology's Role in Delivering Accessible Financial Services to the Poor, Retrieved online on $17^{\text {th }}$ April 2013 from: http://www.gdrc.org/icm/govern/banking-unbanked.pdf

Flynn, B. B. (1994). The Relationship between Quality Management Practices, Infrastructure and Fast Product Innovation. Benchmarking for Quality Management \& Technology, 1(1), 48-64. http://dx.doi.org/10.1108/14635779410056886

Freeman, C., \& Soete, L. (1997). The Economics of Industrial Innovation, London and Washington: Pinter.

Ghana Statistical Service (GSS). (2007). Patterns and Trends of Poverty in Ghana (1999-2006). GSS, Accra, Ghana.

Gupta, S. (2008). Microfinance in Africa: Harnessing the Potential of a Continent. Microfinance Insight. An Intellecap Publication.

Hamel, G. (2000). Resource attraction. Executive Excellence, August, 3-4.

Helms, B. (2006). Access for All: Building inclusive Financial System. Washington: CJAP/World Bank Release.

International Monetary Fund. (2005). Microfinance: A View from the Fund. IMF Paper, Washington DC. Retrieved online on $17^{\text {th }}$ April 2013 from www.imf.org/external/np/pp/eng/2005/012505.pdf

Investopedia. (2013). Definition of microinsurance. Retrieved online on $27^{\text {th }}$ April 2013 from www.investopedia.com/terms/m/microinsurance.asp.

ISSER. (2012). The state of the Ghanaian economy in 2011. Institute of Statistical, Social and Economic Research, University of Ghana, Legon, Accra, Ghana.

Lafourcade, A., Isern, J., Mwangi, P., \& Brown, M. (2005). Overview of the Outreach and Financial Performance of Microfinance Institutions in Africa. Retrieved online on $20^{\text {th }}$ April 2013 from

http://www.themix.org/sites/default/files/MBB\%2012\%20-\%20Outreach\%20and\%20Financi al\%20Performance\%20of\%20African\%20MFIs.pdf.

Lin, J. Y. (1990). Education and Innovation Adoption in Agriculture: Evidence from Hybrid Rice in China. 73(3), 713-723. http://dx.doi.org/10.2307/1242823

Littlefield, E., Murduch, J., \& Hashemi, S. (2003). Is Microfinance an Effective Strategy to Reach the Millennium Development Goals? Focus Note Series no. 24. Washington: CGAP -Consultative Group to Assist the Poor. 


\section{MInstitute ${ }_{\text {Mnk }}^{\text {Macrothin }}$}

Business and Economic Research ISSN 2162-4860

Lovelock, C. H. (1984). Developing and Implementing New Services: in George, W.R. and Marko Wski. (2002) Financial Services to large and how income earners, A textbook, 1st edition, pages 99-117 McGraw-Hill Publication Limited, Netherland.

Marshall, C.E. (Eds), Developing New Services, American Marketing Association, Chicago, IL, 44-64.

Mix, M. (2005). Microfinance and its Activities, Jurblin Publication, University of New York Press. 50-88,

MoFEP. (2008). General Background on Global Microfinance Trends. Ministry of Finance and Economic Planning, Government of Ghana. Available at http://www.microfinancegateway.org/p/site/m/template.rc/1.9.46118/_

Mytelka, L. K. (2000). Local Systems of Innovation in a Globalized World Economy. Industry and Innovation, 7(1), June, 15-32. http://dx.doi.org/10.1080/713670244

Nana Opare-Djan, N. (2008). Microfinance Product Development in Ghana: the Innovative and Uniqueness Dimensions of Kraban Support Foundation's Microloan Products. The Third Annual Microfinance of the UCC, held from the 10th to 11th January, 2008 at the Elmina Beach Resort, Cape Coast, Ghana.

Nugroho, Y., \& Miles, I. (2009). Global Review of Innovation Intelligence and Policy Studies, Mini Study 06 - Microfinance \& Innovation. A Project for DG Enterprise and Industry. The European Commission.

OECD. (2005). Oslo Manual: Guidelines for Collecting and Interpreting Innovation Data, Third Edition. OECD, Paris.

Pearce, J. A., \& Robinson, R. B. (2011). Strategic Management. Formulation, Implementation, and Control. (12 $2^{\text {th }}$ Ed.) McGraw-Hill International Edition.

Porter, M. E., \& Stern, S. (2001). Innovation: location matters. MIT Sloan Management Review, Summer, 28-36. http://dx.doi.org/10.1596/0-8213-4524-9.

Porter, M. E. (1998). The Competitive Advantage of Nations. MacMillan.

Rajalahti, R., Janssen, W., \& Pehu, E. (2008). Agricultural Innovation Systems: From Diagnostics toward Operational Practices. Agriculture and Rural Development Discussion Paper 38, The World Bank.

Robinson, M. (2001).The Microfinance Revolution: Sustainable Finance for the Poor. Washington, DC: The World Bank. Pp. xlvii, 304.

Schmidt, T., \& Rammer, C. (2006). The Determinants and Effects of Technological and non-Technological Innovations-Evidence from the German Eurostat and the Member States of the European Union. Fourth Community Innovation Survey (CIS IV).

Spielman, D. J. (2005). Innovation Systems Perspectives on Developing-Country Agriculture: A Critical Review. ISNAR Discussion Paper. International Food Policy Research Institute. 


\section{Macrothink}

Business and Economic Research ISSN 2162-4860

Steel, F. W., \& Andah, O. D. (2003). Rural and Micro Finance Regulation in Ghana: Implications for Development and Performance of the Industry. Africa Region Working Paper Series No. 49.

Tempkin, T. (2011). Finding the Right Board Size. Retrieved online on $27^{\text {th }}$ April 2013 from www.philanthropyjournal.org/resources/.../finding-right-board-size.

Terberger, E. (2003). Microfinance Institutions in the Development of Financial Markets. CEPAL REVIEW 81. 187-202.

UNCDF. (2006). Microfinance and the Millennium Development Goals: A reader's guide to the Millennium Project Reports and other UN documents. International Year of Microcredit 2005.

Vilaseca-Requena, J., Torrent-Sellens, J., \& Jime'nez-Zarco A. N. (2007). ICT use in Marketing as Innovation Success Factor -Enhancing cooperation in new Product Development Processes. European Journal of Innovation Management, 10(2), 268-288. http://dx.doi.org/10.1108/14601060710745297.

Wenner, M. (2002). Contribution at Symposium on Microfinance in the Caribbean.

World Bank. (1994). Findings-Africa Region. No. 26. Washington DC.

\section{Copyright Disclaimer}

Copyright reserved by the author(s).

This article is an open-access article distributed under the terms and conditions of the Creative Commons Attribution license (http://creativecommons.org/licenses/by/3.0/). 